\title{
THE POTENTIAL OF HIGH RESOLUTION MELTING ANALYSIS (HRMA) TO STREAMLINE, FACILITATE AND ENRICH ROUTINE DIAGNOSTICS IN MEDICAL MICROBIOLOGY
}

\author{
Lenka Ruskova ${ }^{a}$, Vladislav Raclavskya,b*
}

\begin{abstract}
a Department of Microbiology, Faculty of Medicine and Dentistry, Palacky University Olomouc, Czech Republic
${ }^{b}$ Institute of Molecular and Translational Medicine, Faculty of Medicine and Dentistry, Palacky University Olomouc

E-mail:vladislav.raclavsky@upol.cz
\end{abstract}

Received: December 15, 2010; Accepted: July 20, 2011

Key words: High Resolution Melting Analysis/HRMA/Microbial identification/Strain typing/Genotyping

Background. Routine medical microbiology diagnostics relies on conventional cultivation followed by phenotypic techniques for identification of pathogenic bacteria and fungi. This is not only due to tradition and economy but also because it provides pure culture needed for antibiotic susceptibility testing. This review focuses on the potential of High Resolution Melting Analysis (HRMA) of double-stranded DNA for future routine medical microbiology.

Methods and Results. Search of MEDLINE database for publications showing the advantages of HRMA in routine medical microbiology for identification, strain typing and further characterization of pathogenic bacteria and fungi in particular. The results show increasing numbers of newly-developed and more tailor-made assays in this field. For microbiologists unfamiliar with technical aspects of HRMA, we also provide insight into the technique from the perspective of microbial characterization.

Conclusions. We can anticipate that the routine availability of HRMA in medical microbiology laboratories will provide a strong stimulus to this field. This is already envisioned by the growing number of medical microbiology applications published recently. The speed, power, convenience and cost effectiveness of this technology virtually predestine that it will advance genetic characterization of microbes and streamline, facilitate and enrich diagnostics in routine medical microbiology without interfering with the proven advantages of conventional cultivation.

\section{INTRODUCTION}

While molecular-genetic techniques have been rapidly implemented in detection and identification of microorganisms that cannot be cultivated, grow very slowly in culture or require special techniques, their use in the case of other microbes is still limited. For bacterial species that have no special requirements for growth, conventional cultivation followed by phenotypic identification still represents the golden standard in routine medical microbiology not only because of tradition and economy but also because it provides pure culture needed for antibiotic susceptibility testing. In the case of fungal species, susceptibility testing is typically not performed: However, conventional techniques are well-proven and recovery of a limited number of cultures of a rather broad spectrum of yeast and mold species discourages development of new techniques and implementing them for routine use. On the other hand, accurate and detailed genetic characterization became increasingly important when the differences among species and genotypes were recognized as fequently playing an important role in health and disease. Therefore, we expect the routine availability of the newly available elegant technique of high-resolution melting analysis (HRMA) in medical microbiology laboratories should provide a strong stimulus in this field. This is already envisioned by the growing number of specific HRMA applications published in medical microbiology recently. In this review, we will therefore focus on this fermenting topic. The principle and important technical aspects of melting analysis will be elucidated first for those unfamiliar with the technique, followed by a summary of the remarkable repertoire of its applications already introduced into diagnostic medical microbiology, bacteriology and mycology in particular.

\section{TECHNICAL ASPECTS OF MELTING ANALYSIS}

\section{Principle of the technique}

As widely known, the course of thermal double-stranded DNA (dsDNA) denaturation, shortly called DNA melting, largely depends on two basic features of a dsDNA molecule, namely length and sequence. Because the two strands of dsDNA are bound together by hydrogen bonds between base pairs, the longer the molecule, the more thermal energy is needed for its separation (melting). In addition, G-C base pairs form 3 hydrogen bonds, while A-T pairs only two. Hence, with more G-C pairs present in a given molecule, more energy is also needed for melting. This provides a unique link between both the length and sequence of a dsDNA molecule and its easily measurable physical characteristic. Historically, melting properties of dsDNA were monitored by measuring UV absorbance (hyperchromic effect). Such analysis required $\mu \mathrm{g}$ amounts of DNA and often took hours to complete. 
With the introduction of the first real-time PCR instrument that combined thermal cycler with a fluorimeter, fluorescent DNA melting analysis became popular at the end of 1990s. This analysis requires only ng amounts of DNA and small sample volumes allow both better temperature control and fast melting rates of $0.1-1.0{ }^{\circ} \mathrm{C} / \mathrm{s}$, shortening the melting analysis time to a few minutes.

Typically, PCR amplification of a desired DNA region precedes DNA melting analysis for all kinds of different purposes. Due to its rapid and simple performance, melting analysis competes successfully with traditional techniques of post-PCR analysis, like conventional gel electrophoresis, analysis of single-stranded conformational polymorphism (SSCP), denaturing gradient gel electrophoresis (DGGE) and temperature gradient gel electrophoresis (TGGE) (ref. ${ }^{1}$ ). The best system for detection, quantification and examination of sequence specificity of PCR products would work simultaneously with amplification and no further analysis would be necessary $^{1,2}$. A closed system of this kind can be achieved by using dsDNA fluorescent dyes in melting analysis or fluorescent labelled allele-specific probes in real time PCR (ref. ${ }^{1}$ ). In addition, both techniques can be combined in one assay using compatible fluorescent chemistries. Alternatively, asymmetric PCR can also be combined with the use of unlabelled probes, where dsDNA fluorescent dyes allow for the monitoring of probe/DNA melting behaviour. Typically, melting analysis provides valuable data in the field of pre-sequencing analysis and is even able to replace sequencing in specific areas of analysis. Its applications span wide areas of research and diagnostics, including mutation discovery (gene scanning), genotyping of single nucleotide polymorphisms (SNPs), and DNA methylation analysis.

When monitoring the process of DNA melting, we should bear in mind that it is not a linear event, because cooperative forces enhance the stability of a dsDNA molecule in addition to mere hydrogen bonding, and also regions of different $\mathrm{AT} / \mathrm{GC}$ ratio are present along molecules of different sequences. Thus it typically follows a sigmoid curve (Fig. 1a), but it can also follow a more complex pattern in longer molecules. The process of denaturation is most simply characterized by $\mathrm{T}_{\mathrm{m}}$ (melting temperature) which is defined as a temperature where $50 \%$ of present dsDNA molecules are already denaturated into single-stranded DNA (ssDNA).

In fluorescent melting analysis, a fluorescent dsDNA binding dye is added to the reaction mixture prior to amplification. Thus the PCR products already harbour the dye intercalated in their dsDNA. It is also possible to add the dye after PCR itself which may be useful in some cases to avoid dye interference with PCR amplification and/or prevent an increase in optimum annealing temperature of primers. When a PCR product is melted later, molecules of the intercalated fluorescent dye are released from the denatured DNA chain. This is observed as a decrease in fluorescence, and can be plotted as a melting curve of unique shape (Fig.1b).

\section{Acquisition and processing of melting data}

Typically, the whole process of PCR amplification and melting analysis takes place in a closed tube without manual intervention ${ }^{2}$. The PCR amplification and melting analysis are either both performed in a real-time PCR instrument that also enables melting analysis, or the PCR tube or capillary are transferred from a thermal cycler to a melting instrument. A melting curve is plotted based on fluorescence data acquired during melting as a function of dissociation temperatures during heating of the sample. Thus denaturation of a PCR product saturated by a dsDNA dye is observed as a sudden decrease of fluorescence near $\mathrm{T}_{\mathrm{m}}$ (ref. $^{2}$ ). Before this sharp decrease can be observed, a constant slow decrease in fluorescence with temperature increase is observed. This so-called premelt domain reflects just physical changes in the relative fluorescence intensity caused by increasing temperature. Once a sharp decrease is observed, the dsDNA melting is reflected in the melt domain of the curve, followed by another constant slow decrease in fluorescence with temperature when dsDNA melting is complete and the dsDNA melting domain flows into post-melt domain (all Fig. 2a). When acquiring fluorescence data during heating of a sample containing dsDNA, the interval between start and stop temperature for data acquisition has to be set wide enough to include the process of melting represented by sharp decrease of fluorescence.

It should be mentioned that the melting behaviour of a PCR product is affected not only by its intrinsic properties but also by the concentration of the dsDNA dye and the rate of temperature transition ${ }^{2}$. In addition, PCR amplification also results in different yields of PCR product which further influences the melting analysis. Therefore, reaction parameters should if possible be optimised for a given assay and then kept unchanged for reproducible performance, including the PCR yield. However, even with best optimisation, exactly constant and reproducible yields can never be achieved. Thus each of the curves representing raw fluorescent melting data starts at a different point on the $\mathrm{Y}$ axis, corresponding to the relative fluorescence intensity of the sample at the beginning of analysis. Therefore, individual melting curves and their characteristics based on such data cannot be compared directly; they have to be normalised before any comparison. This is done through software-driven numerical recalculation of individual melting data points which results in unifying the starting values of all curves on $100 \%$ relative fluorescence intensity and their endpoints at $0 \%$ relative fluorescence intensity (Fig. 3a). In order to provide reference data for such normalisation, parts of the pre-melt and post-melt domains that are considered unaffected by melting behaviour of the dsDNA have to be defined first. Selection of such reference intervals cannot be automated and has to be optimised empirically for each newly developed assay, because choosing different intervals results in differences in final shaping of normalised melting domains. At least, choice of intervals which result in apparently unnatural or bizarre appearance of normalised melting curves has to be avoided. Once optimised, the 

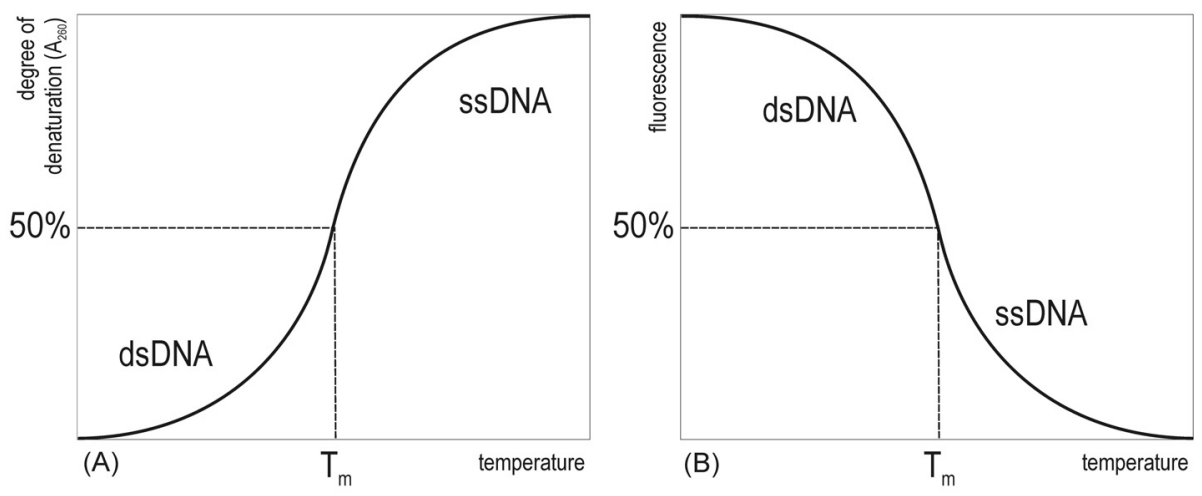

Fig. 1. Process of dsDNA denaturation. Degree of denaturation during temperature increase as monitored by increase of absorbance at $260 \mathrm{~nm}(\mathrm{~A})$ and by decrease of fluorescence of intercalating fluorescent dye (B).
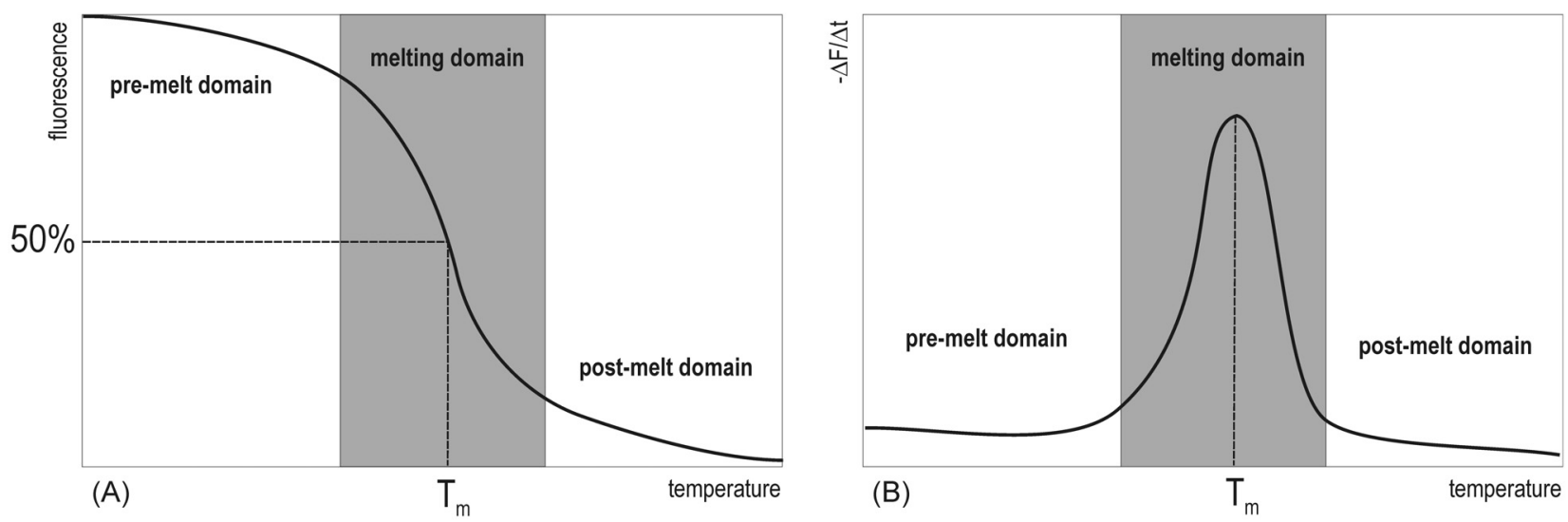

Fig. 2. Fluorescent melting analysis. Normalised fluorescent melting curve with a typical melting domain (A) and the first negative derivation of fluorescence depending on temperature based on same data showing typical melting peak (B).

same intervals have to be set in repeated experiments of the same assay to secure reproducibility of melting data interpretation.

Adjustment of melting data along the $\mathrm{X}$ axis (temperature) may also be advantageous in addition to vertical normalisation of melting data described above (Fig. 3b). Namely, increased concentration of an intercalating dye can cause a shift of melting curves to higher temperatures. The same is true when dsDNA concentration in one sample is considerably lower than in other samples because this moves the dye/dsDNA ratio towards relatively higher concentration of dye. If more dye molecules saturate the DNA duplex in one sample than others, the more they contribute to the stability of the duplex and thus increase its melting temperature relatively. The whole melting curve is then shifted to the right along the $\mathrm{X}$ axis. In addition, rapid temperature transitions during denaturation can shift melting curves to higher temperatures as well ${ }^{2}$. Last but not least, well-to-well temperature variation in block-type melting instruments always requires temperature shift normalization for proper interpretation of melting data. For this reason temperature shifting normalization is typically necessary in block-type melting instruments but in the case of air-controlled melting instruments with rotary design this is only a desirable or unnecessary.

After desirable normalization is performed, derivation of melting data can be performed, which in many cases enables better visual reading of differences between melting curves and also offers convenient accurate reading of $T_{m}$. Derivative curves are typically constructed by calculating the first negative derivation of fluorescence with temperature $(-\Delta \mathrm{F} / \Delta \mathrm{t})$. In effect, such transformation of a melting curve results in a plot that shows a peak, representing the melting domain of a dsDNA molecule (Fig. 2b). In its first portion, a derivative curve corresponds to the pre-melt domain where absence of marked decrease in relative fluorescence results in a linear, flat appearance. However, once the fluorescence starts to decrease sharply with the beginning of dsDNA melting, its negative derivation plots a sharp increase in the derivative curve. After the sigmoid curve of decreasing fluorescence reaches inflexion point and the decrease in fluorescence decelerates, the negative derivative curve reaches a peak value and starts to drop again. This inflexion point in the sigmoid normalized curve and apex of the peak in the derivative curve both represent $\mathrm{T}_{\mathrm{m}}$ of the dsDNA molecule melted. Obviously, it is much easier to read a peak 

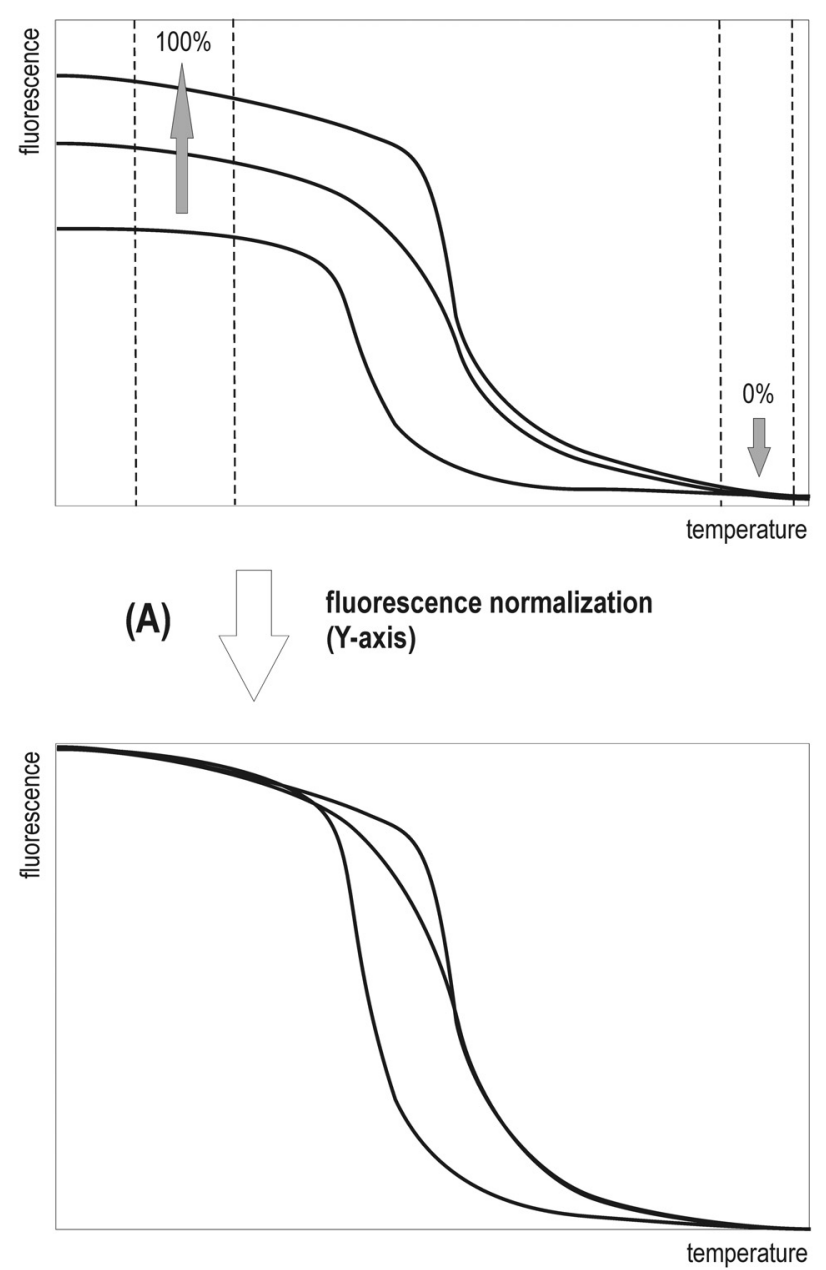

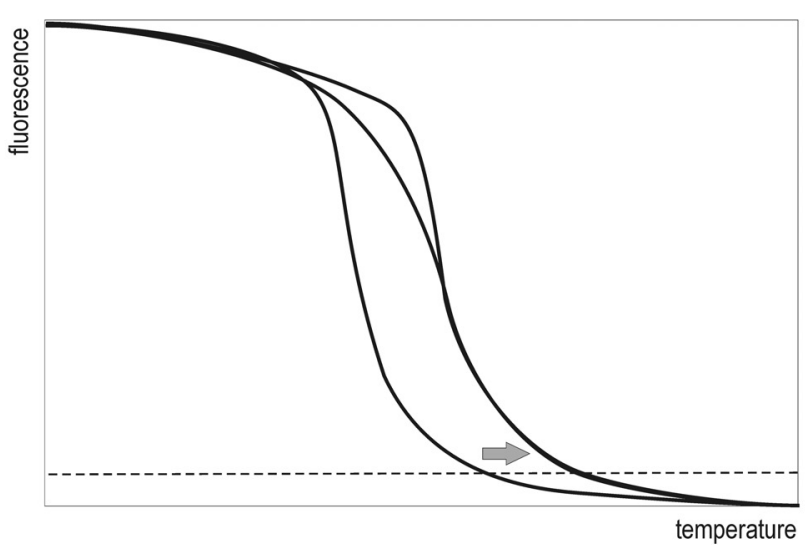

(B)

temperature shift (X-axis)

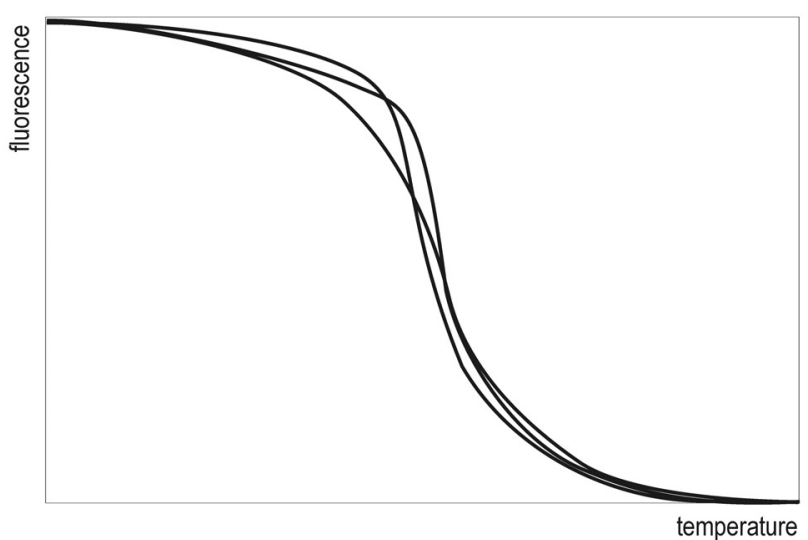

Fig. 3. Normalization of fluorescent melting data. Intervals in the pre-melt and post-melt domains are user-defined for normalization to the $100 \%$ and $0 \%$ relative fluorescence value, respectively (A). When needed, temperatureshift is performed to compensate for possible differences in the onset of melting, caused by unequal reaction conditions (B).

in a derivative curve than identify the inflexion point in a sigmoid curve. Shorter PCR products typically melt with a single domain and a single peak, whereas more complex longer molecules may melt differently in different stretches, resulting in complex melting domains and more than one peak in a derivative curve. This should also be kept in mind when focusing on a target for PCR amplification followed by melting analysis. Melting analysis has traditionally been most widely used in the field of SNP scanning and genotyping where the most extensive experience has also been accumulated. However, even in this field, the number of melting domains optimal for analysis remains controversial $^{3}$. Apparently, different settings and targets of interest may require different strategies to achieve best reproducible and readable data. Overall, derivative curve provides better clues for interpretation of melting behavior and differentiation of sequence variants in many cases due to better readability of $\mathrm{T}_{\mathrm{m}}$, and difference in the height and shape of peaks which may also improve visualizing differences in melting domains.

The shape and $T_{m}$ of a dsDNA melting curve is a function of its GC content, length, and sequence ${ }^{2}$. With dif- ferent molecules, $T_{m}$ and shape of its melting curve can vary over a wide range. According to empirical formulas, duplexes with $0 \% \mathrm{GC}$ content melt at $41^{\circ} \mathrm{C}$ lower than $100 \%$ GC duplexes. When the GC content is the same in products of different length, the smaller product should melt at lower temperature and thus be easily distinguishable $^{2}$. Differences in melting curve shapes, especially in regions which reflect minute sequence differences in melted dsDNA molecules, can be analyzed in detail by subtracting all curves from a reference curve (e.g. a curve obtained with a wild-type sequence/allele). This helps to cluster samples automatically into groups that have similar melting curves. Clustering of curves is simply evaluated visually and can be very helpful and reliable particularly in SNP assays if validated carefully (so-called differential plot). Typically, those melting curves obtained from individuals whose one allele is mutated and who are thus heterozygotes, cluster together as opposed to curves obtained from wild-type homozygotes. Such analysis is particularly helpful both in genotyping and mutation scanning, including screening for new, unknown mutations (in microbiology see e.g. Issa et al. ${ }^{4}$ ). 


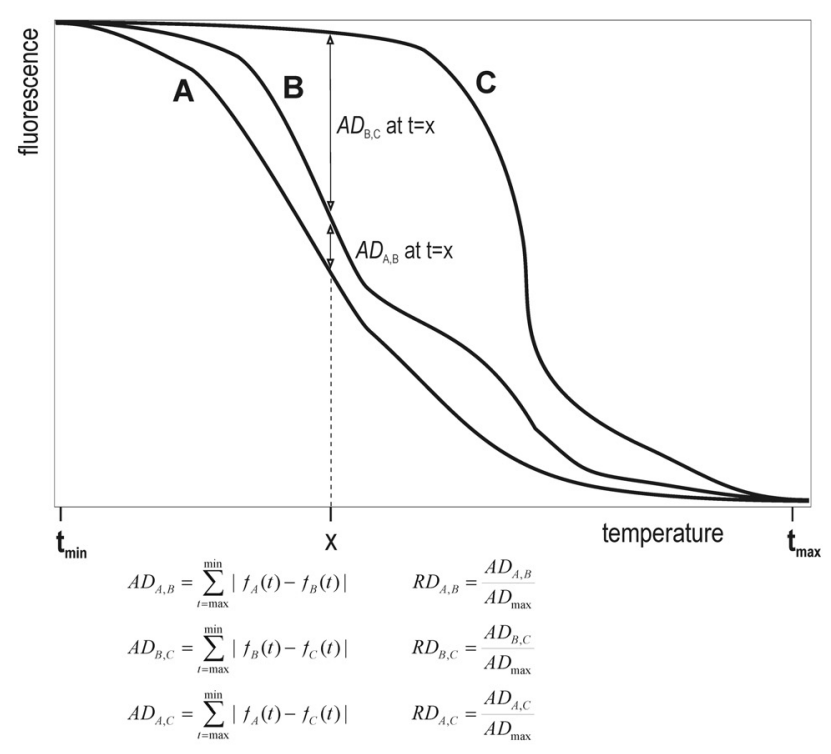

Matrix of relative distances:

\begin{tabular}{c|c|c|c|} 
& $\mathrm{A}$ & $\mathrm{B}$ & $\mathrm{C}$ \\
\hline $\mathrm{A}$ & 0 & $R D_{A, B}$ & $R D_{A, C}$ \\
\hline $\mathrm{B}$ & $R D_{A, B}$ & 0 & $R D_{B, C}$ \\
\hline $\mathrm{C}$ & $R D_{A, C}$ & $R D_{B, C}$ & 0 \\
\hline
\end{tabular}

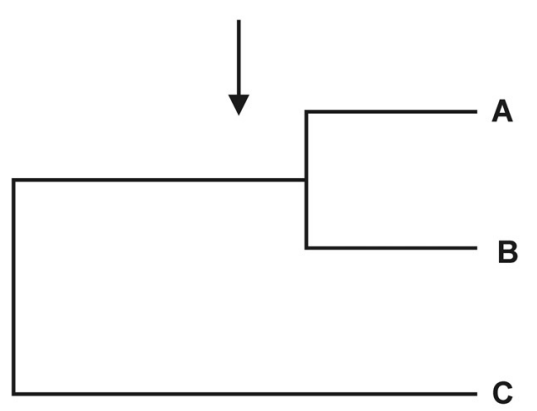

Fig. 4. Automated comparison of McRAPD data. Melting curves of RAPD products are compared by calculating absolute distance between each pair of samples; relative distances are then recalculated to prepare a matrix of relative distances that are used to calculate tree data using e.g. the UPGMA algorithm. For details see text and Trtkova et al. ${ }^{5}$.

Recently, another type of quantitative numerical comparison of complex melting curves was proposed which can be useful for targeting highly variable sequences useful e.g. for species identification in microbiology (Fig. 4). This approach was first used in processing of McRAPD data $^{5}$, which can be useful both for species identification and strain typing. Briefly, normalized fluorescence values measured at each temperature point during melting analysis are subtracted in each pair of compared curves. Then, the sum of these subtracted values represents absolute numerical distance between two curves. After such distances are assigned to all pairs of curves studied, the highest value of 1.0 relative distance is assigned to the highest absolute distance obtained and the other absolute distances are re-calculated relatively. A matrix of such relative distances then represents a matrix of similarity coefficients and can be used to calculate tree data for a cladogram that will cluster the curves according to their degree of similarity, thereby providing visually easily readable comparison of similarity between large numbers of complex melting curves.

\section{Fluorescent dsDNA specific dyes and High-Resolution Melting Analysis (HRMA)}

As real-time PCR became a standard method both in research and routine use, many improvements in the area of fluorescent intercalating dyes were made. Many dyes were tested and evaluated as compatible with PCR chemistry and then became available for product staining as well as quantification during qPCR (Table 1). Several other intercalating fluorescent dsDNA dyes were not tested for PCR-compatibility and some of these may also prove to be useful.

Table 1. Fluorescent intercalating dyes useful for qPCR monitoring and fluorescent melting analysis.

\begin{tabular}{|l|c|c|}
\hline \multicolumn{1}{|c|}{ Dye } & $\begin{array}{c}\text { Max. excitation/emis- } \\
\text { sion wavelength (nm) } \\
\text { of dsDNA complex }\end{array}$ & Reference \\
\hline BEBO $^{\circledR}$ & $468 / 492$ & 6 \\
\hline BOXTO $^{\circledR}$ & $515 / 552$ & 7 \\
\hline Ethidium bromide & $518 / 605$ & 8 \\
\hline EVAGreen $^{\circledR}$ & $500 / 530$ & 9,10 \\
\hline LCGreen $^{\circledR}$ & $440-470 / 470-520$ & 11 \\
\hline ResoLight $^{\circledR}$ & $487 / 503$ & 12 \\
\hline SYBR $^{\circledR}$ Green & $497 / 520$ & 2,13 \\
\hline SYTO $^{\circledR}$ dyes & $485 / 498$ & 14,15 \\
\hline YO-PRO-1 $^{\circledR}$ & $491 / 509$ & 15 \\
\hline
\end{tabular}

Further improvement of the technique came with the introduction of High Resolution Melting Analysis (HRMA) which can be performed on melting instruments that are capable of acquiring fluorescence data at high density during DNA melting (approx. 50 data points are acquired for every $1{ }^{\circ} \mathrm{C}$ ). When this technology was introduced, some of the dyes turned out to be more appropriate than others for HRMA. Also, some of the dyes showed better performance in specific fields of detection. For best performance, a dsDNA dye has to show low toxicity for PCR and high saturation of the dsDNA molecule. Low toxicity dyes can be included in the PCR reaction during its assembly and thus enable post-PCR melting analysis without opening the reaction tube. This is both convenient and time saving and it significantly reduces the risk of carryover contamination of future amplification reaction. Saturating dyes improve the resolution and accuracy of melting analysis in contrast to low saturation dyes not only because of increased fluorescence, but also because low saturation dyes redistribute from one part of a dsDNA molecule to another during melting to some extent in contrast to saturation dyes which show low dy- 
Non-saturating dye
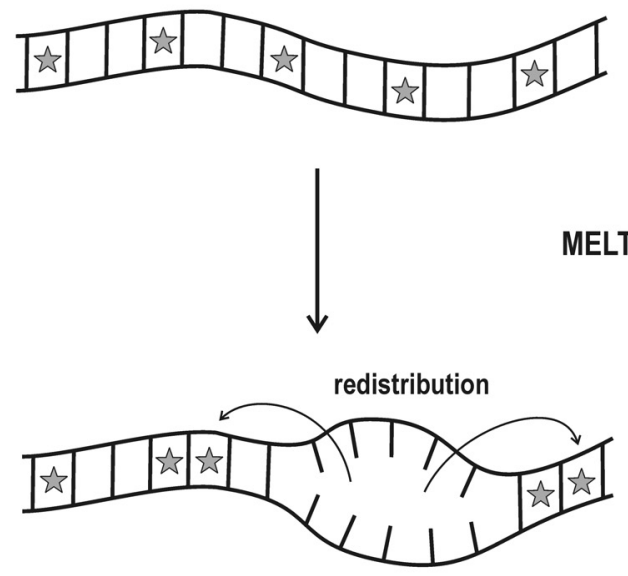

No decrease in fluorescence or reduced decrease in fluorescence
Saturating dye

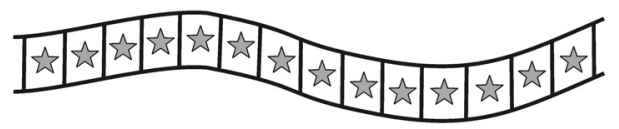

MELTING

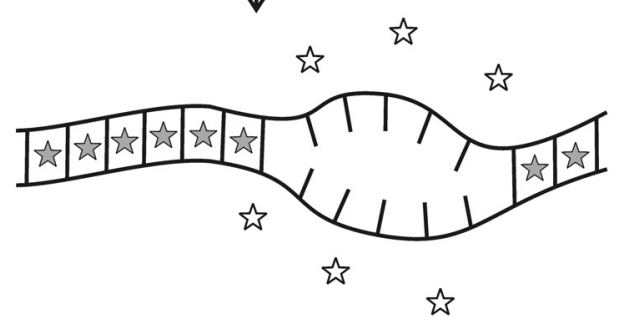

Proportional decrease in fluorescence

Fig. 5. Melting analysis with saturating vs. non-saturating dye. See text for details.

namic redistribution ${ }^{11}$ (Fig. 5). These requirements are met by the so-called third generation intercalating fluorescent dyes, namely SYTO 9 (Invitrogen Corp. Carlsbad, CA, USA), LCGreen (Idaho Technology Inc., Salt Lake City, UT, USA) and EvaGreen (Biotium Inc., Hayward, CA, USA).

All of the third generation dyes are declared to show high stability, low inhibition of PCR and high saturation. However direct comparison of their performance in HRMA is missing. Results of comparisons of individual dyes to the conventional SYBR Green I dye are cited when respective dyes are described. Obviously, results of any such comparison would also depend upon the specific application for which the dyes would be tested. Only one group directly compared more than 2 dyes and concluded LCGreen Plus detects heterozygotes better than SYTO 9, which is better than EvaGreen, which is better than SYBR Green I ( ref. $\left.^{16}\right)$. Of course, when choosing a dye for a specific HRMA application, excitation and emission characteristics should first be confronted with the real-time and melting instrumentation available because not all instruments are compatible with all of the dyes available. Then inter-run variability of melting data obtained with different dyes, $\mathrm{T}_{\mathrm{m}}$ of individual melting peaks in particular, should be evaluated further for the best choice in a specific application. Last but not least, economy of performance can also play a significant role because of marked differences in pricing of individual dyes. When the utmost precision of HRMA for the purpose of SNP genotyping and homozygotes/heterozygotes genotyping is not the primary goal, less accurate but more economic options may be preferred. This is true for instance when gross differences in melting temperatures need to be evaluated e.g. for species identification purposes in microorganisms, as will be reviewed later.

\section{Limitations of melting curve analysis}

As any other technique, melting curve analysis has its limitations and potential pitfalls. Firstly, fluorescent intercalating dyes can bind to any dsDNA molecule, including primer dimers, and the detection of desired products is therefore dependent on product specific PCR $\left(\right.$ ref. $\left.^{2}\right)$. Whereas conventional gel electrophoresis of PCR products can usually easily unravel potential non-specific byproducts of amplification, fluorescent dyes lack sequence specificity and any non-specific by-products will bias the results of melting analysis. Therefore, closed-tube PCRHRMA assays that omit conventional gel electrophoresis have to be optimised carefully and their performance should be strictly controlled if used for diagnostic purposes.

Secondly, all the components present at the time of melting analysis or during PCR amplification have a great impact on the melting curve shape and position. The absolute position and width of a melting curve are affected by dye concentration and temperature transition rates. Finer resolution is available with slower transition rates and greater sample homogeneity ${ }^{2}$. In addition, although many commercial platforms are available for real-time PCR and HRMA or HRMA separately, significant differences have been described in the uniformity of melting data obtained from different instruments when performing the same assay ${ }^{17}$. Thus, again, PCR-HRMA assays have to be optimised carefully for reliable performance on the same platform and using the same reagents. On the other hand, such optimisation efforts are typically adequately rewarded by high-throughput, economy, and simple and accurate performance of HRMA or PCR-HRMA. In addition to prevention of carryover contamination mentioned above, HRMA also provides much more information on the product then mere molecule length visualization, namely sequence-dependent shape of the curve and its 
$\mathrm{T}_{\mathrm{m}}$, enabling differentiation of products of the same size but different sequence.

\section{MELTING ANALYSIS IN MEDICAL MICROBIOLOGY}

\section{Application potential in specific fields}

In comparison to conventional approaches, various molecular-genetic techniques, in vitro nucleic acid amplification in particular, have led to improvements in the diagnosis of infectious diseases and to the detection time reduction, for overview see e.g. Espy et al. ${ }^{18}$. Such techniques can be typically performed either on primarily sterile clinical samples to speed up the process of detection and identification, or on pure culture of microorganisms when speed of detection is not critical and antibiotic susceptibility testing is also desirable. Molecular methods can be extremely helpful when conventional diagnostics is difficult and other tests are not reliable. The advent of real-time PCR revolutionized molecular techniques in medical microbiology, for overview see Espy et al. ${ }^{18}$. Combination of PCR and HRMA can contribute to the advantages of molecular-genetic techniques mainly by replacing post-PCR techniques or labeled probes that are not only more laborious but typically also more costly.

Generally, PCR-HRMA can be applied in three areas in medical microbiology, i.e. for species identification, for strain typing and also for genotyping of specific genes (allele detection). Detection and identification go hand in hand when performing PCR-HRMA on clinical sample directly, but as with any molecular-genetic technique, PCR-HRMA can of course also be applied on pure culture already recovered by conventional cultivation. Because conventional phenotypic identification techniques are well elaborated for routine use, molecular techniques, incl. PCR-HRMA, are only under development in the field of routine pure culture identification. In contrast, molecular-genetic typing of microorganism for epidemiological purposes is by large the most widely adopted genetic approach in medical microbiology because of its superior discriminatory power compared to phenotyping techniques. However, it is typically performed only in advanced laboratories retrospectively. Last but not least, molecular-genetic techniques also predominate when detection of specific alleles and/or genes is desired in particular species by advanced laboratories.

Except for nucleic-acid free prions, PCR-HRMA is applicable to any bacterial, viral or parasite species and has the potential to streamline the process of characterization of isolates for all the purposes listed above. Compared to hybridization or sequencing, which can serve the same purposes, HRMA offers an economic closed-tube approach performed instantly after PCR amplification and suitable for automation in future. For this reason, it is expanding in microbiology as reflected in new applications published at a growing pace. As with any new microbiological method, however, HRMA is firstly implemented on microorganisms causing serious diseases, where speed of any diagnostic test is crucial. In the next section, we will summarize HRMA applications published in the fields of species identification, strain typing and genotyping of specific alleles. The use of HRMA in detection of microorganisms will not be discussed separately because generally all the techniques suitable for HRMA species identification should also be applicable for detection in clinical samples following appropriate DNA extraction and assay optimization. However, when broad-range primers are used that are able to amplify DNA from more then one species, the use of HRMA is limited in clinical samples that harbour more then one species. This is because broad-range PCR primers will in such case amplify the same locus but with variable sequences in different species in parallel. Then, melting of a mixture of such variable amplicons will result in a mixed melting curve where individual melting behaviour of any of the mixed amplicons cannot be differentiated retrospectivelly. Therefore, those systems developed for broad-range detection can be applied only on primary sterile samples, where only single species can typically be expected, whereas narrowrange systems should also be applicable in most cases of samples containing mixed microbiota. Nevertheless, extraction of bacterial or fungal DNA of quality suitable for HRMA can be problematic from clinical samples in some cases. For better overview, all the applications discussed below are also summarized separately (Table 2).

\section{Melting analysis for species identification purposes}

An amplification target useful for species identification should harbor both conserved sequences well suited for primer design and variable sequences that can serve subsequent identification. The degree of conservation and variability required can vary depending on the spectrum of species desired for amplification and identification. When panfungal or panbacterial coverage is the goal, the highest degree of conservation is paramount. In such cases, however, it is a major challenge to achieve a degree of product variability sufficient for reliable differentiation and identification of all targeted species as well. Following amplification, either the whole product can undergo melting analysis or a product-probe hybrid can be examined. Also, more amplification targets can be analyzed in parallel, either separately or in a multiplex reaction. In reality, true panbacterial coverage is hardly possible; however, coverage of e.g. all aerobic bacterial species potentially significant in health and disease should be feasible. Such strategy is then termed broad-range amplification. For evolutionary reasons, the $16 \mathrm{~S}$ rRNA gene in bacteria and the 18S - ITS1 - 5.8S - ITS2 - 28S rRNA transcription unit in fungi which are both highly conserved and contain variable sequences characteristic for particular species, are most widely used for broad-range amplification. The fact that these regions have long been studied in detail also speaks in their favor because sequence data of rRNA genes are generally available in databases, even for bacterial and fungal species that are otherwise rarely studied. Other genes conserved across kingdoms may represent an alternative to the rRNA genes, as described e.g. by Santos 
and Ochman ${ }^{19}$. However, these have not been explored for species identification based on melting analysis so far. Techniques not dependent upon specific sequences or those targeting broadly shared repetitive sequences, e.g. RAPD (Random Amplified Polymorphic DNA) or repPCR, can provide another alternative, as demonstrated in the McRAPD approach ${ }^{5,20,21}$.

In the field of broad-range bacterial species identification, Klaschik et al. ${ }^{22}$ were the first to develop a PCR and melting analysis assay using 2 probes for identification of 17 common bacterial species. In 2006, Cheng et al. ${ }^{23}$ differentiated and identified 46 bacterial culture colonies representing 25 clinically important species using a LightCycler real-time PCR instrument for amplification of the 16S rRNA gene in the presence of the LC Green I fluorescent dye and a HR-1 melting instrument for melting profiles, without using any probe. Simplicity and smartness of this assay that promised rapid and economic bacterial species identification in future was instantly recognized and commented on in Editorial ${ }^{24}$. However, a well-proved broader coverage is desirable for routine use. So far, the best achievement towards an optimum system was made by Yang et al. ${ }^{25}$, who covered 100 clinically important bacterial species, though, reproducibility and specificity of this assay in routine use still has to be evaluated.

In the field of routine broad-range identification of fungal species, the McRAPD approach was the first technique that successfully implemented melting analy$\operatorname{sis}^{20}$. It performs well in identification of pure culture of pathogenic yeast species and has its strong point in partial strain subtyping ${ }^{5}$, that can be particularly useful for epidemiological surveillance and that also has the potential to discover new cryptic yeast species in future as happened with RAPD in the recent past (Candida dubliniensis vs. C. albicans, Candida orthopsilosis and metapsilosis vs. $C$. parapsilosis). Owing to the principle of RAPD, its interlaboratory reproducibility will always be limited however although it can outdo conventional techniques in several aspects when optimized carefully ${ }^{5}$. It should also be noted, that because of the digital data obtained in melting analysis the McRAPD approach can be used for automated strain typing, as demonstrated by Hamal et al. ${ }^{26}$. For those who do not want to spend too much time with optimization and who also resign on typing for epidemiological purposes, specific amplification targeting yeast ITS1 and ITS2 regions should be very useful ${ }^{27}$. Both of the above assays are however suitable only for identification of pure culture recovered by cultivation because both McRAPD and ITS primers will amplify variable sequences in variable species. Then, when mixed culture would be processed, a mixture of variable amplicons would result in a mixed melting curve during HRMA and it would be impossible to differentiate individual melting behaviour of any of the mixed amplicons retrospectivelly. When seeking a rapid diagnostic assay performed directly on clinical samples, a system that detects a narrower range of the most important yeast and mold pathogens with high sensitivity, accuracy and reproducibility should be used.
Dozens of such systems were published using real-time PCR with probes but none of them were widely accepted. The assay developed by Schabereiter-Gurtner et al. ${ }^{28}$ combines good targeting (group-specific and universal primers) with species-specific biprobes in one reaction mixture, analyzed by melting analysis. In our opinion, this is the best one elaborated for routine use.

Although broad-range species identification is the most attractive application of HRMA in routine diagnostic microbiology, in many areas, narrow-range or genus-range systems may be extremely helpful as well. For instance, species-level identification of a staphylococcal isolate can be highly important as staphylococci cause a variety of serious infections and are threatening public health worldwide. It is known that in $30 \%$ of nosocomial infections and in 50\% of nosocomial septicemia, coagulase-negative staphylococci (CoNS) are most commonly isolated $^{29}$. Rapid and accurate identification based on HRMA can e.g. facilitate proper differentiation of true bloodstream infections caused by the same repeatedly recovered CoNS species in contrast to transient occurrence of changing species in blood samples of high-risk patients. In the study of Skow et al. ${ }^{30}$, unique melt profiles of product-probe hybrids resulting from sequence variations were observed and identification of 110 staphylococcal isolates achieved nearly $100 \%$ accuracy. Another good example is the system that targets the 16S rRNA gene in Nocardia strains ${ }^{31}$. Nocardiosis is usually an opportunistic infection, most commonly present as pulmonary disease. Its definitive diagnosis depends on microbiological identification and cultivation is time consuming ( 2 weeks of microbiological cultivation and susceptibility tests in contrast to 1 day PCR-HRMA assay). Similar to Nocardia sp., rapid performance and high intra-genus resolution are also very important in detection and identification of mycobacterial pathogens. In particular, differentiation of $M$. tuberculosis from nontuberculosis mycobacteria (NTM) has primary importance in the control of the infection and in choice of antimicrobial therapy. Although there are several commercial tests for mycobacteria identification available as Accuprobe (Gen-Probe Incorporated, San Diego, California), these require growth in culture to identify four commonly encountered and/or clinically significant mycobacteria reliably. The GenoType ${ }^{\circledR}$ MTBC (Hain Lifescience GmbH, Nehren, Germany), a DNA - Strip ${ }^{\circledR}$ technology based test able to identify 40 Mycobacterium species, is rather similar. Another alternative is the INNO-LiPA line probe assay (Innogenetics N.V., Ghent, Belgium) for detection of mycobacteria and their identification at the species level but the test is costly. In addition, COBAS Amplicor real-time PCR assay followed by probe hybridization detected by colorimetric reaction (Roche Diagnostics, Mannheim, Germany) is available for mycobacterial detection and identification. All of these commercially available systems are laborious and less economic than PCR-HRMA. Then, Shrestha et al. ${ }^{32}$ developed a real-time PCR detection with 2 probes followed by melting curve analysis for differentiation of nine NTM species. This assay was comparable to COBAS 
Amplicor and, in addition, it also appropriately characterized three acid-fast bacillus positive clinical specimens that contained $M$. avium, $M$. intracellulare, or $M$. kansasii as containing NTM rather than $M$. tuberculosis, in a parallel study ${ }^{32}$. Melting analysis was also demonstrated to be successful in inter-species differentiation of the $M$. chelonae-abscessus group that consists of $M$. chelonae, $M$. abscessus and M. immunogenum that are difficult to distinguish in the clinical laboratory ${ }^{33}$. A major contribution to rapid and accurate differential identification of Mycobacterium species was provided by the development of a real-time PCR with 21 HybProbes that identified 25 different Mycobacterium species based on melting data $^{34}$. Differentiation of the pathogenic amoeboflagellate Naegleria fowleri from nonpathogenic Naegleria species using a single primer set and intercalating dye SYTO9 for real-time PCR and melting curve analysis of the ITS15.8S rRNA-ITS2 region is another good example of useful narrow-range differentiation of pathogenic species from their benign counterparts that is particularly useful for monitoring of bathing water, water supplies, and cooling systems $^{35}$.

\section{Melting analysis for genotyping purposes}

Although melting analysis for the purpose of species identification can also be considered a genotyping approach, genotyping in the narrow sense means determination of specific genotypes of strains or alleles of genes. This is particularly useful for either epidemiological analysis and/or surveillance or for detection of alleles underlying clinically relevant phenotypes, e.g. in antibiotic resistance genes, virulence genes etc. In the field of strain typing, a recently developed well-directed and carefully elaborated assay nicely demonstrates the versatile power of HRMA in genotyping in the case of MRSA typing for epidemiological purposes ${ }^{36}$, a hot topic in medical microbiology. The ongoing effort to develop an HRMA typing scheme for Campylobacter jejuni and $C$. coli represents another good example of a well-elaborated approach. Namely, Price et al. ${ }^{37}$ first developed a HRMA assay for interrogating the hypervariable CRISPR (cluster, regularly interspaced short palindromic repeats) locus of Campylobacter jejuni. To improve the power of resolution and extend the spectrum to $C$. coli, the same group elaborated an HRMA approach to detection of sequence variants of the fla $A$ flagellin gene ${ }^{38}$. Because of its easy and rapid performance and potential for full automation, melting analysis of RAPD products may also be useful for epidemiological surveillance in the future. Whereas MLST is a reference approach for large scale surveillance and for population biology studies, there also remains a need for rapid, less laborious and cheap approaches, such as McRAPD, on a local scale ${ }^{21}$. McRAPD may be usefull mainly in such species where other molecular typing schemes are not easily available or are laborious, e.g. for serovars of Leptospira as demonstrated by Tulsiani et al..$^{39}$, or for less frequently occurring yeasts as demonstrated by Hamal et al. ${ }^{26}$ in the emerging pathogenic yeast C. lusitaniae. Comparison of McRAPD with MLST data in five Gram-negative bacterial species showed that McRAPD could be used to rapidly identify major clones of these species, including multidrug-resistant and particularly virulent clones ${ }^{21}$. It can also serve typing of pathogens where RAPD typing schemes are well-established and there is no need to develop more sophisticated molecular approaches in the near future, e.g. in Aspergillus sp. ${ }^{40}$. In the field of virology, Lin et al. ${ }^{41}$ developed high resolution melting analysis for subtype differentiation of the influenza A virus and for detection of newly emerging variants. The influenza B virus has also been studied using the melting curve analysis by Nakagawa et al. ${ }^{42}$, who demonstrated that the assay not only detected its antigenic variants but also allowed for more precise analysis of the antigenic shifts in the influenza B virus. A HRMA assay detecting and genotyping noroviruses directly from stool samples was also developed and successfully validated ${ }^{43}$.

Apropos the detection of virulent genotypes, Reischl et al. ${ }^{44}$ developed a set of real-time PCR assays with melting analysis of product probe-complexes targeting enterotoxin genes in enterotoxigenic Escherichia coli (ETEC). Makinen et al. ${ }^{45}$ focused on Bordetella pertusis with the aim of rapid gene typing of gene variants of the pertussis toxin using hybridization probes melting curve analysis. In order to obtain a reliable tool for detection of Bacillus anthracis and B. cereus, Kim et al. ${ }^{46}$ developed a multiplex real-time PCR melting curve analysis. A high degree of relatedness was demonstrated by several methods. Most of them failed in discriminating among some members of the $B$. cereus group. While virulence is defined by the presence of both virulence plasmids, either of these can be lost, in the laboratory or in nature, generating 4 different genotypes. The discrimination among $B$. anthracis and $B$. cereus is then difficult. The melting analysis assay was able to provide a rapid, inexpensive and sensitive tool to simultaneously detect, from purified genomic DNA, all $B$. anthracis virulence genotypes and near-neighbor B. cereus group chromosomes ${ }^{46}$. De Medici et al.$^{47}$ performed a specific reaction with primers targeting the region coding for a major subunit protein of a fimbrial structure on the surface of Salmonella enterica serotype Enteritidis. Specificity of the reaction was determined by melting analysis. Stephens et al. ${ }^{48}$ tested successfully the hypothesis that HRMA can be useful for differentiation of spa alleles in methicilin-resistant Staphylococcus aureus (MRSA) isolates.

In the field of antibiotic treatment and resistance, the extended-spectrum beta-lactamases (ESBLs) represent a significant challenge. For this reason, several HRM assays were developed to detect mutations or alleles responsible for this phenotype. Chia et al. ${ }^{49}$ developed a multiplex PCR to identify $b l a_{\mathrm{SHV}}, b l a_{\text {СТХ-M-3 }}$-like and bla $a_{\text {СТХ-M-14 }}-$ like genes and also modified a previously described SHV melting-curve mutation detection (MCMD) method ${ }^{50}$ to rapidly differentiate the 6 bla $a_{\mathrm{SHV}}$ genes prevalent in Taiwan. Specific detection of bla ${ }_{\mathrm{VIM}}$ and $b l a_{\mathrm{IMP}}$ metallo$\beta$-lactamase genes in a single real-time PCR was tested by Bisilkis et al. ${ }^{51}$. The genes were clearly differentiated into four groups ( $b l a_{\mathrm{VIM}-1}-1 \mathrm{like}, b l a_{\mathrm{VIM}-2}-1 \mathrm{like}, b l a_{\mathrm{IMP}-1}-1 \mathrm{like}$, and 
Table 2. Overview of published HRMA assays useful in medical microbiology.

\begin{tabular}{|c|c|c|c|c|}
\hline Microorganism(s) & Amplification target & Melting target & Platform and chemistry & Reference \\
\hline \multicolumn{5}{|c|}{ 1. Broad-range species identification } \\
\hline 17 various bacterial species & 16S rRNA gene & $\begin{array}{l}\text { whole product } \\
\text { and } 2 \text { FRET } \\
\text { probes }\end{array}$ & LightCycler $^{1}$ & 22 \\
\hline 5 or 9 pathogenic yeast species & whole genome & $\begin{array}{l}\text { mixture of RAPD } \\
\text { products }\end{array}$ & $\begin{array}{l}\text { LightCycler }{ }^{1}, \text { HR-1ㄴ, SYBR } \\
\text { Green, LC Green }\end{array}$ & 5,20 \\
\hline 25 various bacterial species & 16S rRNA gene & whole product & $\begin{array}{l}\text { LightCycler }{ }^{1}, \mathrm{HR}^{-1}{ }^{2}, \mathrm{LC} \\
\text { Green }\end{array}$ & 23 \\
\hline 14 pathogenic yeast species & $\begin{array}{l}\text { 18S, 5.8S and 28S rRNA } \\
\text { gene }\end{array}$ & whole product & Rotor-Gene ${ }^{3}$, SYBR Green & 27 \\
\hline $\begin{array}{l}11 \text { pathogenic yeast and mold } \\
\text { species }\end{array}$ & ITS2 region & biprobes & LightCycler $^{1}$, SYBR Green & 28 \\
\hline $\begin{array}{l}\text { Candida albicans, C. dublinien- } \\
\text { sis }\end{array}$ & $\begin{array}{l}\text { ITS2 region of the rRNA } \\
\text { genes }\end{array}$ & whole product & LightCycler $^{1}$, SYBR Green & 55 \\
\hline 100 various bacterial species & 16S rRNA gene & whole product & LightScanner $^{2}$, LC Green & 25 \\
\hline 111 various species & 16S rRNA gene & $\begin{array}{l}\text { sloppy molecular } \\
\text { beacons }\end{array}$ & ABI Prism ${ }^{4}$ & 56 \\
\hline \multicolumn{5}{|c|}{ 2. Narrow-range genus or species identification } \\
\hline Bacillus anthracis, B. cereus & $\begin{array}{l}\text { sspE chromosomal gene, } \\
\text { cap } C \text { gene of the } \mathrm{pXO} 2 \\
\text { plasmid, lef gene of the } \\
\text { pXO1 plasmid gene }\end{array}$ & whole product & LightCycler $^{1}$, SYBR Green & 46 \\
\hline $\begin{array}{l}\text { Mycobacterium chelonae-absces- } \\
\text { sus group }\end{array}$ & 16S rRNA gene, $h s p 65$ gene & whole product & LightCycler ${ }^{1}$, LC Green & 33 \\
\hline $\begin{array}{l}110 \text { isolates -Staphylococcus } \\
\text { speciation }\end{array}$ & 16S rRNA gene & 2 FRET probes & $\begin{array}{l}\text { LightCycler }{ }^{1}, \text { HR }^{-1}{ }^{2}, \text { LC } \\
\text { Green }\end{array}$ & 30 \\
\hline Nocardia spp. & 16S rRNA gene & whole product & LightCycler $^{1}$, SYBR Green & 31 \\
\hline Aspergillus spp. & ITS1 region, 5.8S rRNA & whole product & $\begin{array}{l}\text { LightCycler }{ }^{1}, \mathrm{HR}-1^{2}, \mathrm{LC} \\
\text { Green }\end{array}$ & 57 \\
\hline Naegleria spp. & $\begin{array}{l}\text { ITS1 and ITS2 region, 5.8S } \\
\text { rRNA }\end{array}$ & whole product & Rotor-Gene ${ }^{3}$, SYTO9 & 35 \\
\hline $\begin{array}{l}6 \text { species of Borrelia burgdorferi } \\
\text { sensu lato }\end{array}$ & $h b b$ gene & $\begin{array}{l}\text { Fluorescein } \\
\text { labelled probe }\end{array}$ & LightCycler $^{1}$ & 58 \\
\hline 18 Mycobacterium spp. & $r p o B$ gene & HybProbes & LightCycler $^{1}$ & 34 \\
\hline 3 species of Leishmania & 7SL RNA gene & whole product & Rotor-Gene ${ }^{3}$, SYTO9 & 59 \\
\hline $\begin{array}{l}\text { Mycoplasma pneumoniae, } \\
\text { Chlamydophila pneumoniae, } \\
\text { Legionella spp. }\end{array}$ & omp $A, P 1,16 \mathrm{~S}$ rRNA gene & whole product & ABI Prism ${ }^{4}$, SYBR Green & 60 \\
\hline \multicolumn{5}{|c|}{ 3. Strain typing for epidemiological purposes } \\
\hline $\begin{array}{l}\text { Salmonella enterica } \text { serotype } \\
\text { Enteritidis }\end{array}$ & sefA region & whole product & ABI Prism ${ }^{4}$, SYBR Green & 47 \\
\hline E. coli - ETEC & LT1 and ST1 genes & $\begin{array}{l}\text { hybridization } \\
\text { probes }\end{array}$ & LightCycler $^{1}$ & 44 \\
\hline Mycoplasma synoviae & vlhA gene & whole product & Rotor-Gene ${ }^{3}$, SYTO9 & 61 \\
\hline Campylobacter jejuni & CRISPR locus & whole product & $\begin{array}{l}\text { Rotor-Gene }{ }^{3}, \text { SYTO9, } \\
\text { SYBR Green }\end{array}$ & 37 \\
\hline 44 MRSA isolates & spa locus & whole product & Rotor-Gene $^{3}$ & 48 \\
\hline Pseudomonas aeruginosa & $\begin{array}{l}20 \text { fragments carrying } \\
\text { SNPs from } 7 \text { housekeeping } \\
\text { genes }\end{array}$ & whole product & Rotor-Gene ${ }^{3}$, SYBR Green & 62 \\
\hline Campylobacter jejuni and C. coli & flaA gene & whole product & Rotor-Gene ${ }^{3}$, SYBR Green & 38 \\
\hline Chlamydia trachomatis & ompA gene & whole product & LightCycler $^{1}$, LC Green & 63 \\
\hline
\end{tabular}




\begin{tabular}{|c|c|c|c|c|}
\hline Microorganism(s) & Amplification target & Melting target & Platform and chemistry & Reference \\
\hline $\begin{array}{l}\text { Achromobacter xylosoxidans, } \\
\text { Acinetobacter bauman- } \\
\text { nii, Klebsiella pneumoniae, } \\
\text { Pseudomonas aeruginosa and } \\
\text { Stenotrophomonas maltophilia }\end{array}$ & whole genome & $\begin{array}{l}\text { mixture of RAPD } \\
\text { products }\end{array}$ & LightCycler $^{1}$, SYBR Green & 21 \\
\hline Candida lusitaniae & whole genome & $\begin{array}{l}\text { mixture of RAPD } \\
\text { products }\end{array}$ & $\begin{array}{l}\text { RapidCycler }{ }^{2}, \mathrm{HR}-1^{2}, \mathrm{LC} \\
\text { Green }\end{array}$ & 26 \\
\hline Candida albicans & $\begin{array}{l}\text { CDC3 locus upstream } \\
\text { fragment }\end{array}$ & whole product & LightCycler $^{1}$, ResoLight & 64 \\
\hline Leptospira serovars & whole genome & $\begin{array}{l}\text { mixture of RAPD } \\
\text { products }\end{array}$ & Rotor-Gene $^{3}$, EvaGreen & 39 \\
\hline Giardia intestinalis & rRNA intergenic spacer & whole product & LightCycler $^{1}$, SYBR Green & 65 \\
\hline Noroviruses genogroups & ORF1-ORF2 junction & whole product & LightCycler $^{1}$, ResoLight & 43 \\
\hline Influenza A virus & Neuraminidase gene & whole product & LightCycler $^{1}$, SYBR Green & 66 \\
\hline \multicolumn{5}{|c|}{ 4. Allele genotyping or mutation screening } \\
\hline $\begin{array}{l}\text { Escherichia coli and Klebsiella } \\
\text { pneumoniae }\end{array}$ & $b l a_{\mathrm{SHV}}$ gene & FRET probes & LightCycler $^{1}$ & 50 \\
\hline $\begin{array}{l}57 \text { isolates and } 2 \text { vaccine strains } \\
\text {-Bordetella pertusis }\end{array}$ & $\begin{array}{l}\text { pertussis toxin gene, } p t x \mathrm{~S} 1 \\
\text { allele }\end{array}$ & FRET probes & LightCycler $^{1}$ & 45 \\
\hline $\begin{array}{l}\text { Escherichia coli, Klebsiella pneu- } \\
\text { moniae, Enterobacter cloacae }\end{array}$ & $\begin{array}{l}\text { bla } a_{\mathrm{SHV}} \text { gene, } b l a_{\mathrm{CTX}-\mathrm{M}-3} \text { like } \\
\text { gene, } b l a_{\text {CTX-M-14 }} \text { like gene }\end{array}$ & $\begin{array}{l}\text { hybridization } \\
\text { probes }\end{array}$ & LightCycler $^{1}$ & 49 \\
\hline HSV & NA & FRET probes & LightCycler $^{1}$, LC Green & 4 \\
\hline Burkholderia cepacia complex & recA gene & FRET probes & LightCycler $^{1}$ & 67 \\
\hline $\begin{array}{l}72 \text { isolates - Streptococcus } \\
\text { pneumoniae }\end{array}$ & $\begin{array}{l}\text { parC gene and the } g y r \mathrm{~A} \\
\text { gene }\end{array}$ & FRET probes & LightCycler $^{1}$ & 53 \\
\hline 211 isolates of enterobacteria & $\begin{array}{l}\text { aminoglycoside acetyltrans- } \\
\text { ferase } a a c\left(6 \_-I b\right.\end{array}$ & $\begin{array}{l}\text { whole product } \\
\text { and unlabelled } \\
\text { probe }\end{array}$ & LightCycler $^{1}$, ResoLight & 68 \\
\hline 55 samples - Helicobacter pylori & $\begin{array}{l}\text { 16S rRNA gene - species, } \\
\text { 23S rRNA gene - point } \\
\text { mutations }\end{array}$ & $\begin{array}{l}\text { hybridization } \\
\text { probes }\end{array}$ & LightCycler $^{1}$ & 54 \\
\hline Gram-negative bacteria & 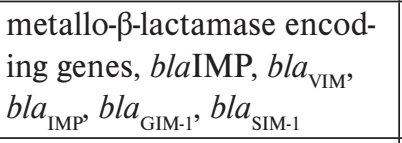 & whole product & $\begin{array}{l}\text { DNA Engine Opticon } 2 \\
\text { system }^{5}, \text { SYBR Green }\end{array}$ & 52 \\
\hline Gram-negative bacteria & bla $a_{\mathrm{VIM}}$ gene, $b l a_{\mathrm{IMP}}$ gene & $\begin{array}{l}\text { LC Red } 640 \\
\text { and fluorescein } \\
\text { probes }\end{array}$ & LightCycler $^{1}$, SYBR Green & 51 \\
\hline Staphylococcus aureus & lukS-PV gene & whole product & Rotor-Gene ${ }^{3}$, SYBR Green & 69 \\
\hline Escherichia coli & $\begin{array}{l}\text { bla genes (TEM, SHV, } \\
\text { CTX-M) }\end{array}$ & whole product & Rotor-Gene, LC Green & 70 \\
\hline Plasmodium falciparum & $d h f r$ gene & unlabelled probe & LightCycler $^{1}$, LC Green & 71 \\
\hline $\mathrm{HCV}$ & $\begin{array}{l}\text { highly conserved } 5^{\prime} \text { non- } \\
\text { coding region }\end{array}$ & FRET probes & LightCycler $^{1}$ & 72 \\
\hline HSV & $\begin{array}{l}\text { glycoprotein } \\
\text { D gene fragment }\end{array}$ & unlabelled probe & $\begin{array}{l}\text { LightCycler }^{1}, \mathrm{HR}^{-1}{ }^{2}, \mathrm{LC} \\
\text { Green }\end{array}$ & 73 \\
\hline Influenza A virus & M-gene fragment & $\begin{array}{l}\text { plasmid with the } \\
\text { M fragment }\end{array}$ & LightCycler $^{1}$, HR-1 ${ }^{2}$ & 41 \\
\hline HIV & gag gene & whole product & $\begin{array}{l}\text { ABI Prism }{ }^{4}, \\
\text { LightScanner }{ }^{2} \text {, LC Green }\end{array}$ & 74 \\
\hline
\end{tabular}

${ }^{1}$ Roche Diagnostics, Roche Applied Science, Indianapolis, Indiana, USA

${ }^{2}$ Idaho Technology Inc., Salt Lake City, Utah, USA

${ }^{3}$ Corbett Research, Sydney, Australia (Qiagen GmbH, Hilden, Germany)*

${ }^{4}$ Applied Biosystems, Forster City, California, USA

${ }^{5}$ Bio-Rad Laboratories, California, USA

*Due to a corporate acquisition the Corbett Rotor-Gene is no longer available, but the Qiagen Rotor-Gene Q is an essentially identical device. 
$b l a_{\mathrm{IMP}-2}-$ like) by melting curve analysis with two probes. On the other hand, Mendes et al. ${ }^{52}$ designed a multiplex system able to detect and differentiate 5 metallo- $\beta$-lactamase genes without the use of probes. As for other types of antibiotic resistance genes, Fukushima et al..$^{53}$ studied, developed and validated a rapid single step PCR-melting assay for genotyping Streptococcus pneumoniae strains, targeting four quinolone resistance-determining region (QRDR) positions that are most frequently associated with fluoroquinolone resistance and Alfaresi et al. ${ }^{54}$ focused both on the presence of clarithromycin resistance genes and virulence attributes (cagA and vacA genes) in Helicobacter pylori, both in subcultured isolates and in gastric mucosal biopsy samples. Their real-time PCR and melting curve analysis assay was able to identify patients suffering from $H$. pylori infection and in addition to identify strains harboring mutations associated with clarithromycin resistance.

\section{CONCLUSIONS}

This review shows that from the increasing number of newly developed applications, implementation of the PCR-HRMA approach is a vigorously fermenting field in all areas of medical microbiology. Although no technique can be expected to resolve all the challenges of modern diagnostic microbiology, a combination of colony-PCR with HRMA has the potential for economic, rapid and accurate characterization of bacterial cultures that can replace conventional phenotypic techniques. PCR-HRMA also has great potential to facilitate, streamline and expand the process of bacterial culture characterization. We can envisage a model situation, where a potentially pathogenic bacterial species is identified in the first step by PCR-HRMA and based on the result of identification, further differentiation of specific genotypes, genomovars or virulence genes may be desired to clarify its true role in health and disease. Although PCR-HRMA can never replace antimicrobial susceptibility testing, it can provide rapid detection of specific resistance genes which cannot be easily or rapidly detected by conventional phenotypic techniques. In all of these cases, template genomic DNA is already extracted from the particular bacterial isolate for the purpose of initial species identification, thus enabling rapid performance of supplementary PCR-HRMA genotyping assays immediately after their need emerges. In the limited number of cases where a PCR-HRMA assay does not produce an unequivocal ultimate result, the option of supplementary sequencing using the same extracted DNA sample is still available. If an economic pyrosequencing technology is applied, such preliminary HRMA characterization (pre-sequencing screening) of the sequencing template will typically also reduce the costs of the following sequencing. With the advent of robotic DNA extraction and pipetting, the whole process has also the potential to be fully automated, and controlled very effectively and conveniently by a qualified microbiologist who can handle large amounts of analyzed cultures in parallel. To conclude, the speed, power, convenience and cost of HRMA, presages that this technology will advance genetic characterization of microbes related to patients and substantially enrich current procedures in routine medical microbiology.

\section{ACKNOWLEDGEMENTS}

Ministry of Education, Youth and Sports (MSM6198959223), Czech Republic, supported this work. Infrastructural part of this project (Institute of Molecular and Translational Medicine) was supported from the Operational Programme Research and Development for Innovations (project CZ.1.05/2.1.00/01.0030).

\section{REFERENCES}

1. de Silva D, Wittwer CT. Monitoring hybridization during polymerase chain reaction. J Chromatogr B Biomed Sci Appl 2000;741:313.

2. Ririe KM, Rasmussen RP, Wittwer CT. Product differentiation by analysis of DNA melting curves during the polymerase chain reaction. Anal Biochem 1997;245:154-60.

3. Wittwer CT. High-resolution DNA melting analysis: advancements and limitations. Hum Mutat 2009;30:857-9.

4. Issa NC, Espy MJ, Uhl JR, Smith TF. Sequencing and resolution of amplified herpes simplex virus DNA with intermediate melting curves as genotype 1 or 2 by LightCycler PCR assay. J Clin Microbiol 2005;43:1843-5.

5. Trtkova J, Pavlicek P, Ruskova L, Hamal P, Koukalova D, Raclavsky V. Performance of optimized McRAPD in identification of 9 yeast species frequently isolated from patient samples: potential for automation. BMC Microbiol 2009;9:234.

6. Bengtsson M, Karlsson HJ, Westman G, Kubista M. A new minor groove binding asymmetric cyanine reporter dye for real-time PCR. Nucleic Acids Res 2003;31:e45.

7. Lind K, Stahlberg A, Zoric N, Kubista M. Combining sequencespecific probes and DNA binding dyes in real-time PCR for specific nucleic acid quantification and melting curve analysis. Biotechniques 2006;40:315-9.

8. Higuchi R, Dollinger G, Walsh PS, Griffith R. Simultaneous amplification and detection of specific DNA sequences. Biotechnology (N Y) 1992;10:413-7.

9. White HE, Hall VJ, Cross NC. Methylation-sensitive high-resolution melting-curve analysis of the SNRPN gene as a diagnostic screen for Prader-Willi and Angelman syndromes. Clin Chem 2007;53:1960-2.

10. Mao F, Leung WY, Xin X. Characterization of EvaGreen and the implication of its physicochemical properties for qPCR applications. BMC Biotechnol 2007;7:76.

11. Wittwer CT, Reed GH, Gundry CN, Vandersteen JG, Pryor RJ. High-resolution genotyping by amplicon melting analysis using LCGreen. Clin Chem 2003;49:853-60.

12. Schutz E, von Ahsen N. Influencing factors of dsDNA dye (highresolution) melting curves and improved genotype call based on thermodynamic considerations. Anal Biochem 2009;385:143-52.

13. Wittwer CT, Herrmann MG, Moss AA, Rasmussen RP. Continuous fluorescence monitoring of rapid cycle DNA amplification. Biotechniques 1997;22:130-1,4-8.

14. Monis PT, Giglio S, Saint CP. Comparison of SYTO9 and SYBR Green I for real-time polymerase chain reaction and investigation of the effect of dye concentration on amplification and DNA melting curve analysis. Anal Biochem 2005;340:24-34. 
15. Gudnason H, Dufva M, Bang DD, Wolff A. Comparison of multiple DNA dyes for real-time PCR: effects of dye concentration and sequence composition on DNA amplification and melting temperature. Nucleic Acids Res 2007;35:e127.

16. Farrar JS, Reed GH, Wittwer CT. High-Resolution Melting Curve Analysis for Molecular Diagnostics. In: Patrinos GP, Ansorge W, editors. Molecular Diagnostics. Burlington: Elsevier; 2010. p. 229 45.

17. Herrmann MG, Durtschi JD, Wittwer CT, Voelkerding KV Expanded instrument comparison of amplicon DNA melting analysis for mutation scanning and genotyping. Clin Chem 2007;53:1544-8.

18. Espy MJ, Uhl JR, Sloan LM, Buckwalter SP, Jones MF, Vetter EA, Yao JD, Wengenack NL, Rosenblatt JE, Cockerill FR, 3rd, Smith TF. Real-time PCR in clinical microbiology: applications for routine laboratory testing. Clin Microbiol Rev 2006;19:165-256.

19. Santos SR, Ochman H. Identification and phylogenetic sorting of bacterial lineages with universally conserved genes and proteins. Environ Microbiol 2004;6:754-9.

20. Plachy R, Hamal P, Raclavsky V. McRAPD as a new approach to rapid and accurate identification of pathogenic yeasts. J Microbiol Methods 2005;60:107-13.

21. Deschaght P, Van Simaey L, Decat E, Van Mechelen E, Brisse S, Vaneechoutte M. Rapid genotyping of Achromobacter xylosoxidans, Acinetobacter baumannii, Klebsiella pneumoniae, Pseudomonas aeruginosa and Stenotrophomonas maltophilia isolates using melting curve analysis of RAPD-generated DNA fragments (McRAPD). Res Microbiol 2011;162:386-92.

22. Klaschik S, Lehmann LE, Raadts A, Book M, Gebel J, Hoeft A, Stuber F. Detection and differentiation of in vitro-spiked bacteria by real-time PCR and melting-curve analysis. J Clin Microbiol 2004;42:512-7.

23. Cheng JC, Huang CL, Lin CC, Chen CC, Chang YC, Chang SS, Tseng CP. Rapid detection and identification of clinically important bacteria by high-resolution melting analysis after broad-range ribosomal RNA real-time PCR. Clin Chem 2006;52:1997-2004.

24. Reischl U. Melting of the ribosomal RNA gene reveals bacterial species identity: a step toward a new rapid test in clinical microbiology. Clin Chem 2006;52:1985-7.

25. Yang S, Ramachandran P, Rothman R, Hsieh YH, Hardick A, Won H, Kecojevic A, Jackman J, Gaydos C. Rapid identification of biothreat and other clinically relevant bacterial species by use of universal PCR coupled with high-resolution melting analysis. J Clin Microbiol 2009;47:2252-5

26. Hamal P, Hanzen J, Horn F, Trtková J, Rusková L, Vecerová R, Ruzicka F, Volleková A, Raclavský V. Usefulness of McRAPD for typing and importance of biofilm production in a case of nosocomial ventriculoperitoneal shunt infection caused by Candida lusitaniae. Folia Microbiol (Praha) doi:10.1007/s 12223-011-0063-8.

27. Bergman A, Fernandez V, Holmstrom KO, Claesson BE, Enroth H Rapid identification of pathogenic yeast isolates by real-time PCR and two-dimensional melting-point analysis. Eur J Clin Microbiol Infect Dis 2007;26:813-8.

28. Schabereiter-Gurtner C, Selitsch B, Rotter ML, Hirschl AM, Willinger B. Development of novel real-time PCR assays for detection and differentiation of eleven medically important Aspergillus and Candida species in clinical specimens. J Clin Microbiol 2007;45:906-14.

29. Cormican MG, Jones RN. Emerging resistance to antimicrobial agents in gram-positive bacteria. Enterococci, staphylococci and nonpneumococcal streptococci. Drugs 1996;51 Suppl 1:6-12.

30. Skow A, Mangold KA, Tajuddin M, Huntington A, Fritz B, Thomson RB, Jr., Kaul KL. Species-level identification of staphylococcal isolates by real-time PCR and melt curve analysis. J Clin Microbiol 2005;43:2876-80.

31. Alfaresi M, Elkosh A. Rapid identification of clinically relevant Nocardia species using real-time PCR with SYBR Green and melting-curve analysis. J Med Microbiol 2006;55:1711-5.

32. Shrestha NK, Tuohy MJ, Hall GS, Reischl U, Gordon SM, Procop GW. Detection and differentiation of Mycobacterium tuberculosis and nontuberculous mycobacterial isolates by real-time PCR. J Clin Microbiol 2003;41:5121-6.
33. Odell ID, Cloud JL, Seipp M, Wittwer CT. Rapid species identification within the Mycobacterium chelonae-abscessus group by high-resolution melting analysis of hsp65 PCR products. Am J Clin Pathol 2005;123:96-101.

34. Lim SY, Kim BJ, Lee MK, Kim K. Development of a realtime PCR-based method for rapid differential identification of Mycobacterium species. Lett Appl Microbiol 2008;46:101-6.

35. Robinson BS, Monis PT, Dobson PJ. Rapid, sensitive, and discriminating identification of Naegleria spp. by real-time PCR and melting-curve analysis. Appl Environ Microbiol 2006;72:5857-63.

36. Reischl U, Frick J, Hoermansdorfer S, Melzl H, Bollwein M, Linde HJ, Becker K, Kock R, Tuschak C, Busch U, Sing A. Singlenucleotide polymorphism in the SCCmec-orfX junction distinguishes between livestock-associated MRSA CC398 and human epidemic MRSA strains. Euro Surveill 2009;14:19436.

37. Price EP, Smith H, Huygens F, Giffard PM. High-resolution DNA melt curve analysis of the clustered, regularly interspaced shortpalindromic-repeat locus of Campylobacter jejuni. Appl Environ Microbiol 2007;73:3431-6.

38. Merchant-Patel S, Blackall PJ, Templeton J, Price EP, Tong SY, Huygens F, Giffard PM. Campylobacter jejuni and Campylobacter coli genotyping by high-resolution melting analysis of a flaA fragment. Appl Environ Microbiol 2010;76:493-9.

39. Tulsiani SM, Craig SB, Graham GC, Cobbold RC, Dohnt MF, Burns MA, Leung LK, Field HE, Smythe LD. High-resolution meltcurve analysis of random-amplified-polymorphic-DNA markers, for the characterisation of pathogenic Leptospira. Ann Trop Med Parasitol 2010;104:151-61.

40. Raclavsky V, Trtkova J, Ruskova L, Buchta V, Bolehovska R, Vackova M, Hamal P. Primer R108 performs best in the RAPD strain typing of three Aspergillus species frequently isolated from patients. Folia Microbiol (Praha) 2006;51:136-40.

41. Lin JH, Tseng CP, Chen YJ, Lin CY, Chang SS, Wu HS, Cheng JC. Rapid differentiation of influenza A virus subtypes and genetic screening for virus variants by high-resolution melting analysis. J Clin Microbiol 2008;46:1090-7.

42. Nakagawa T, Higashi N, Nakagawa N. Detection of antigenic variants of the influenza B virus by melting curve analysis with LCGreen. J Virol Methods 2008;148:296-9.

43. Tajiri-Utagawa E, Hara M, Takahashi K, Watanabe M, Wakita T. Development of a rapid high-throughput method for high-resolution melting analysis for routine detection and genotyping of noroviruses. J Clin Microbiol 2009;47:435-40.

44. Reischl U, Youssef MT, Wolf H, Hyytia-Trees E, Strockbine NA. Real-time fluorescence PCR assays for detection and characterization of heat-labile I and heat-stable I enterotoxin genes from enterotoxigenic Escherichia coli. J Clin Microbiol 2004;42:4092-100.

45. Makinen J, Mertsola J, Viljanen MK, Arvilommi H, He Q. Rapid typing of Bordetella pertussis pertussis toxin gene variants by LightCycler real-time PCR and fluorescence resonance energy transfer hybridization probe melting curve analysis. J Clin Microbiol 2002;40:2213-6.

46. Kim K, Seo J, Wheeler K, Park C, Kim D, Park S, Kim W, Chung SI, Leighton T. Rapid genotypic detection of Bacillus anthracis and the Bacillus cereus group by multiplex real-time PCR melting curve analysis. FEMS Immunol Med Microbiol 2005;43:301-10.

47. De Medici D, Croci L, Delibato E, Di Pasquale S, Filetici E, Toti L. Evaluation of DNA extraction methods for use in combination with SYBR green I real-time PCR to detect Salmonella enterica serotype enteritidis in poultry. Appl Environ Microbiol 2003;69:3456-61.

48. Stephens AJ, Inman-Bamber J, Giffard PM, Huygens F. High-resolution melting analysis of the spa repeat region of Staphylococcus aureus. Clin Chem 2008;54:432-6.

49. Chia JH, Chu C, Su LH, Chiu CH, Kuo AJ, Sun CF, Wu TL. Development of a multiplex PCR and SHV melting-curve mutation detection system for detection of some SHV and CTX-M beta-lactamases of Escherichia coli, Klebsiella pneumoniae, and Enterobacter cloacae in Taiwan. J Clin Microbiol 2005;43:4486-91.

50. Randegger CC, Hachler H. Real-time PCR and melting curve analysis for reliable and rapid detection of SHV extended-spectrum betalactamases. Antimicrob Agents Chemother 2001;45:1730-6. 
51. Bisiklis A, Papageorgiou F, Frantzidou F, Alexiou-Daniel S. Specific detection of blaVIM and blaIMP metallo-beta-lactamase genes in a single real-time PCR. Clin Microbiol Infect 2007;13:1201-3.

52. Mendes RE, Kiyota KA, Monteiro J, Castanheira M, Andrade SS, Gales AC, Pignatari AC, Tufik S. Rapid detection and identification of metallo-beta-lactamase-encoding genes by multiplex real-time PCR assay and melt curve analysis. J Clin Microbiol 2007;45:544-7.

53. Fukushima KY, Hirakata Y, Sugahara K, Yanagihara K, Kondo A, Kohno S, Kamihira S. Rapid screening of topoisomerase gene mutations by a novel melting curve analysis method for early warning of fluoroquinolone-resistant Streptococcus pneumoniae emergence. J Clin Microbiol 2006;44:4553-8.

54. Alfaresi MS, Abdulsalam AI, Elkoush AA. Analysis of Helicobacter pylori antimicrobial susceptibility and virulence genes in gastric mucosal biopsies in the United Arab Emirates. Indian J Gastroenterol 2007;26:221-4.

55. Somogyvari F, Doczi I, Serly J, Ahmad S, Nagy E. Rapid discrimination between Candida albicans and Candida dubliniensis by using real-time polymerase chain reaction. Diagn Microbiol Infect Dis 2007;58:367-9.

56. Chakravorty S, Aladegbami B, Burday M, Levi M, Marras SA, Shah D, El-Hajj HH, Kramer FR, Alland D. Rapid universal identification of bacterial pathogens from clinical cultures by using a novel sloppy molecular beacon melting temperature signature technique. J Clin Microbiol 2010;48:258-67.

57. Erali M, Pounder JI, Woods GL, Petti CA, Wittwer CT. Multiplex single-color PCR with amplicon melting analysis for identification of Aspergillus species. Clin Chem 2006;52:1443-5.

58. Portnoi D, Sertour N, Ferquel E, Garnier M, Baranton G, Postic D. A single-run, real-time PCR for detection and identification of Borrelia burgdorferi sensu lato species, based on the hbb gene sequence. FEMS Microbiol Lett 2006;259:35-40.

59. Nasereddin A, Jaffe CL. Rapid diagnosis of Old World Leishmaniasis by high-resolution melting analysis of the 7SL RNA gene. J Clin Microbiol 2010;48:2240-2.

60. Kerdsin A, Uchida R, Verathamjamrus C, Puangpatra P, Kawakami K, Puntanakul P, Lochindarat S, Bunnag T, Sawanpanyalert P, Dejsirilert S, Oishi K. Development of triplex SYBR green realtime PCR for detecting Mycoplasma pneumoniae, Chlamydophila pneumoniae, and Legionella spp. without extraction of DNA. Jpn J Infect Dis 2010;63:173-80.

61. Jeffery N, Gasser RB, Steer PA, Noormohammadi AH Classification of Mycoplasma synoviae strains using singlestrand conformation polymorphism and high-resolution meltingcurve analysis of the vlhA gene single-copy region. Microbiology 2007; 153:2679-88.

62. Anuj SN, Whiley DM, Kidd TJ, Ramsay KA, Bell SC, Syrmis MW, Grimwood K, Wainwright CE, Nissen MD, Sloots TP. Rapid SNPBased Identification Of Clonal Pseudomonas Aeruginosa Isolates
From Patients With Cystic Fibrosis Using Real-Time PCR And High Resolution Melting Curve Analysis. Clin Microbiol Infect 2011;17:1403-1408.

63. Li JH, Yin YP, Zheng HP, Zhong MY, Peng RR, Wang B, Chen XS. A high-resolution melting analysis for genotyping urogenital Chlamydia trachomatis. Diagn Microbiol Infect Dis 2010;68:36674.

64. Costa JM, Garcia-Hermoso D, Olivi M, Cabaret O, Farrugia C, Lecellier G, Dromer F, Bretagne S. Genotyping of Candida albicans using length fragment and high-resolution melting analyses together with minisequencing of a polymorphic microsatellite locus. J Microbiol Methods 2010;80:306-9.

65. Al-Mohammed HI. Genotypes of Giardia intestinalis clinical isolates of gastrointestinal symptomatic and asymptomatic Saudi children. Parasitol Res 2011;108:1375-1381.

66. Varillas D, Bermejo-Martin JF, Almansa R, Rojo S, Nogueira B, Eiros JM, Rico L, Iglesias V, Lejarazu RO. A new method for detection of pandemic influenza virus using High Resolution Melting analysis of the neuraminidase gene. J Virol Methods 2011;171:2846.

67. Vonberg RP, Haussler S, Vandamme P, Steinmetz I. Identification of Burkholderia cepacia complex pathogens by rapid-cycle PCR with fluorescent hybridization probes. J Med Microbiol 2006;55:721-7.

68. Bell JM, Turnidge JD, Andersson P. aac(6')-Ib-cr genotyping by simultaneous high-resolution melting analyses of an unlabeled probe and full-length amplicon. Antimicrob Agents Chemother 2010;54:1378-80.

69. Tong SY, Lilliebridge RA, Holt DC, Coombs GW, Currie BJ, Giffard PM. Rapid detection of H and R Panton-Valentine leukocidin isoforms in Staphylococcus aureus by high-resolution melting analysis. Diagn Microbiol Infect Dis 2010;67:399-401.

70. Chroma M, Hricova K, Kolar M, Sauer P, Koukalova D. Using newly developed multiplex polymerase chain reaction and melting curve analysis for detection and discrimination of $\beta$-lactamases in Escherichia coli isolates from intensive care patients. Diagn Microbiol Infect Dis doi:10.1016/j.diagmicrobio.2011.06.017.

71. Cruz RE, Shokoples SE, Manage DP, Yanow SK. High-throughput genotyping of single nucleotide polymorphisms in the Plasmodium falciparum dhfr gene by asymmetric PCR and melt-curve analysis. J Clin Microbiol 2010;48:3081-7.

72. Alfaresi MS, Elkoush AA. Determination of hepatitis C virus genotypes by melting-curve analysis of quantitative polymerase chain reaction products. Indian J Med Microbiol 2007;25:249-52.

73. Dames S, Pattison DC, Bromley LK, Wittwer CT, Voelkerding KV. Unlabeled probes for the detection and typing of herpes simplex virus. Clin Chem 2007;53:1847-54.

74. Towler WI, James MM, Ray SC, Wang L, Donnell D, Mwatha A, Guay L, Nakabiito C, Musoke P, Jackson JB, Eshleman SH. Analysis of HIV diversity using a high-resolution melting assay. AIDS Res Hum Retroviruses 2010;26:913-8. 